\title{
REFERENCES
}

The full list of references is published with the online version of this article at

www.australianprescriber.com/magazine/37/6/188/91

1. Australian Institute of Health and Welfare. Surgery in Australian hospitals 2010-11.

www.aihw.gov.au/hospitals/surgery-2010-11 [cited 2014 Nov 3]

2. Australian Bureau of Statistics. 2006. 4102.0 - Australian Social Trends, 1999. Population Projections: Our ageing population. www.abs.gov.au [cited 2014 Nov 3]

3. Ferguson TB Jr, Hammill BG, Peterson ED, DeLong ER, Grover FL, STS National Database Committee. A decade of change - risk profiles and outcomes for isolated coronary artery bypass grafting procedures, 1990-1999: a report from the STS National Database Committee and the Duke Clinical Research Institute. Society of Thoracic Surgeons. Ann Thorac Surg 2002;73:480-9; discussion 489-90.

4. Story DA, Leslie K, Myles PS, Fink M, Poustie SJ, Forbes A, et al. Complications and mortality in older surgical patients in Australia and New Zealand (the REASON study): a multicentre, prospective, observational study. Anaesthesia 2010;65:1022-30.

5. Mangano DT. Perioperative medicine: NHLBI working group deliberations and recommendations. J Cardiothorac Vasc Anesth 2004;18:1-6.

7. Fleisher LA, Beckman JA, Brown KA, Calkins H, Chaikof E, Fleischmann KE, et al. ACC/AHA 2007 guidelines on perioperative cardiovascular evaluation and care for noncardiac surgery: a report of the American College of Cardiology/American Heart Association Task Force on Practice Guidelines (Writing Committee to Revise the 2002 Guidelines on Perioperative Cardiovascular Evaluation for Noncardiac Surgery): developed in collaboration with the American Society of Echocardiography, American Society of Nuclear Cardiology, Heart Rhythm Society, Society of Cardiovascular Anesthesiologists, Society for Cardiovascular Angiography and Interventions, Society for Vascular Medicine and Biology, and Society for Vascular Surgery. Circulation 2007;116:e418-99.

\section{Medicines Australia Code of Conduct:} breaches

The Medicines Australia Code of Conduct guides the promotion of prescription products by pharmaceutical companies. ${ }^{1}$ Each year Medicines Australia publishes a report, from its Code of Conduct Committee, which details all the complaints that have been received about advertising and other promotional activities.
The Table shows the complaints where at least one breach was identified, and more details can be found in the full report. ${ }^{2}$
Key words

Medicines Australia, breaches

\section{Table Breaches of the Code of Conduct July 2013 - June 2014}

\begin{tabular}{|c|c|c|c|}
\hline Company & Brand (generic) name & Material or activity & Sanction \\
\hline AstraZeneca & Brilinta (ticagrelor) & Promotional material & $\$ 10000$ fine \\
\hline $\begin{array}{l}\text { Boehringer } \\
\text { Ingelheim }\end{array}$ & $\begin{array}{l}\text { Micardis, Twynsta } \\
\text { (telmisartan, telmisartan } \\
\text { with amlodipine) }\end{array}$ & $\begin{array}{l}\text { Misleading promotional } \\
\text { materials }\end{array}$ & $\$ 50$ o00 fine \\
\hline Eli Lilly Australia & Axiron (testosterone) & Promotion to the public & $\begin{array}{l}\$ 250000 \text { fine } \\
\text { Corrective letter }\end{array}$ \\
\hline FIT BioCeuticals & D50K (unregistered drug) & $\begin{array}{l}\text { Promotion to the public } \\
\text { on a website }\end{array}$ & $\begin{array}{l}\$ 150000 \text { fine reduced on appeal to } \$ 25000 \\
\text { Changes to website } \\
\text { Compliance audit of all promotional activities }\end{array}$ \\
\hline Novartis & Lucentis (ranibizumab) & $\begin{array}{l}\text { Email to } \\
\text { ophthalmologists }\end{array}$ & $\begin{array}{l}\$ 250000 \text { fine } \\
\text { Materials not to be used again } \\
\text { Corrective letter }\end{array}$ \\
\hline Roche & Actemra (tocilizumab) & $\begin{array}{l}\text { Unapproved products } \\
\text { and indications }\end{array}$ & $\begin{array}{l}\$ 15000 \text { fine } \\
\text { Materials not to be used again }\end{array}$ \\
\hline
\end{tabular}

\section{REFERENCES}

1. Medicines Australia. Code of Conduct. 17th ed. 2012. http://medicinesaustralia com au/files/2010/01/20130328PUB-Edition17-FINAL.pdf [cited 2014 Nov 7]
2. Medicines Australia. Code of Conduct Annual Report 2013-14. http://medicinesaustralia.com.au/files/2014/02/20141107PUB-CoC-AnnualReport-2013_2014.pdf [cited 2014 Nov 7] 